University of Nebraska - Lincoln

DigitalCommons@University of Nebraska - Lincoln

1992

\title{
Residence times in river basins as determined by analysis of long- term tritium records
}

Robert L. Michel

U.S. Geological Survey

Follow this and additional works at: https://digitalcommons.unl.edu/usgsstaffpub

Part of the Earth Sciences Commons

Michel, Robert L., "Residence times in river basins as determined by analysis of long-term tritium records" (1992). USGS Staff -- Published Research. 434.

https://digitalcommons.unl.edu/usgsstaffpub/434

This Article is brought to you for free and open access by the US Geological Survey at DigitalCommons@University of Nebraska - Lincoln. It has been accepted for inclusion in USGS Staff -- Published Research by an authorized administrator of DigitalCommons@University of Nebraska - Lincoln. 
[1]

\title{
Residence times in river basins as determined by analysis of long-term tritium records
}

\author{
Robert L. Michel \\ 431 National Center, US Geological Survey, Reston, VA 22092, USA
}

(Received 7 February 1991: revised and accepted 23 April 1991)

\begin{abstract}
Michel, R.L., 1992. Residence times in river basins as determined by analysis of long-term tritium records. J. Hydrol., 130: 367-378.
\end{abstract}

The US Geological Survey has maintained a network of stations to collect samples for the measurement of tritium concentrations in precipitation and streamflow since the early 1960s. Tritium data from outflow waters of river basins draining $4500-75000 \mathrm{~km}^{2}$ are used to determine average residence times of water within the basins. The basins studied are the Colorado River above Cisco, Utah; the Kissimmee River above Lake Okeechobee, Florida; the Mississippi River above Anoka, Minnesota; the Neuse River above Streets Ferry Bridge near Vanceboro, North Carolina; the Potomac River above Point of Rocks. Maryland; the Sacramento River above Sacramento, California; the Susquehanna River above Harrisburg, Pennsylvania. The basins are modeled with the assumption that the outflow in the river comes from two sources-prompt (within-year) runoff from precipitation, and flow from the long-term reservoirs of the basin. Tritium concentration in the outflow water of the basin is dependent on three factors: (1) tritium concentration in runoff from the long-term reservoir, which depends on the residence time for the reservoir and historical tritium concentrations in precipitation; (2) tritium concentrations in precipitation (the within-year runoff component); (3) relative contributions of flow from the long-term and within-year components. Predicted tritium concentrations for the outflow water in the river basins were calculated for different residence times and for different relative contributions from the two reservoirs. A box model was used to calculate tritium concentrations in the long-term reservoir. Calculated values of outflow tritium concentrations for the basin were regressed against the measured data to obtain a slope as close as possible to 1. These regressions assumed an intercept of zero and were carried out for different values of residence time and reservoir contribution to maximize the fit of modeled versus actual data for all the above rivers. The final slopes of the fitted regression lines ranged from 0.95 to 1.01 (correlation coefficient $>0.96$ ) for the basins studied. Values for the residence time of waters within the basins and average relative contributions of the within-year and long-term reservoirs to outflow were obtained. Values for river basin residence times ranged from 2 years for the Kissimmee River basin to 20 years for the Potomac River basin. The residence times indicate the time scale in which the basin responds to anthropogenic inputs. The modeled tritium concentrations for the basins also furnish input data for urban and agricultural settings where these river waters are used.

\section{INTRODUCTION}

Tritium, a radioisotope of hydrogen, is generally found in nature as part of the water molecule (HTO). In this form, it is an excellent tracer for the 
movement and mixing of water in the hydrosphere and has been applied to a series of oceanographic and hydrologic problems (Brown, 1961; Michel and Suess, 1975; McPhaden and Fine, 1988). One of the major problems in using tritium as a tracer has been the difficulty of determining its input to the systems being studied. Tritium is produced naturally by cosmic-ray spallation, which maintains a steady-state burden of about $3.5 \mathrm{~kg}$ of tritium on the Earth's surface. This natural component was overwhelmed by the addition of tritium from atmospheric detonation of nuclear weapons. Nuclear explosions injected more than $600 \mathrm{~kg}$ of tritium into the atmosphere, of which about $100 \mathrm{~kg}$ is still present on the Earth's surface. Deposition of tritium produced by nuclear-weapons testing occurred as a series of input peaks that began in 1952 and reached a maximum in 1963-1964. Concentrations of tritium in precipitation have decreased since the 1963-1964 period except for small increases in the late 1970s caused by French and Chinese nuclear tests. To study the deposition and outflow of tritium for the continental United States, the US Geological Survey (USGS) has maintained a network of stations to collect precipitation and river water samples for tritium analyses. These stations, which have been in operation since the early 1960s, provide time series that are suitable to study the tritium flux within the continental United States. The deposition data, which have previously been analyzed, provide tritium input data for the continental United States (Michel, 1989a, b). In this paper, the tritium time series for several river basins are analyzed and estimates of the average residence times of ground water in the basins are provided.

\section{RIVER BASIN NETWORK}

The river basins for which data were analyzed in this study are (A) the Colorado River above Cisco, Utah; (B) the Kissimmee River above Lake Okeechobee, Florida; (C) the Mississippi River above Anoka, Minnesota; (D) the Neuse River above Streets Ferry Bridge near Vanceboro, North Carolina; (E) the Potomac River above Point of Rocks, Maryland; (F) the Sacramento River above Sacramento, California; (G) the Susquehanna River above Harrisburg, Pennsylvania (Fig. 1). All of these basins are of moderate size $\left(4500-75000 \mathrm{~km}^{2}\right)$, and tritium concentrations in precipitation will exhibit minimal variations throughout each basin. Tritium enters the basin in precipitation or by molecular exchange when atmospheric water vapor contains higher tritium concentrations than the surface water. Because the surface area of the water in these basins is small, addition of tritium by molecular exchange will be much less than the addition by direct precipitation. Loss of tritium from the system is through runoff, evapotranspiration, or 


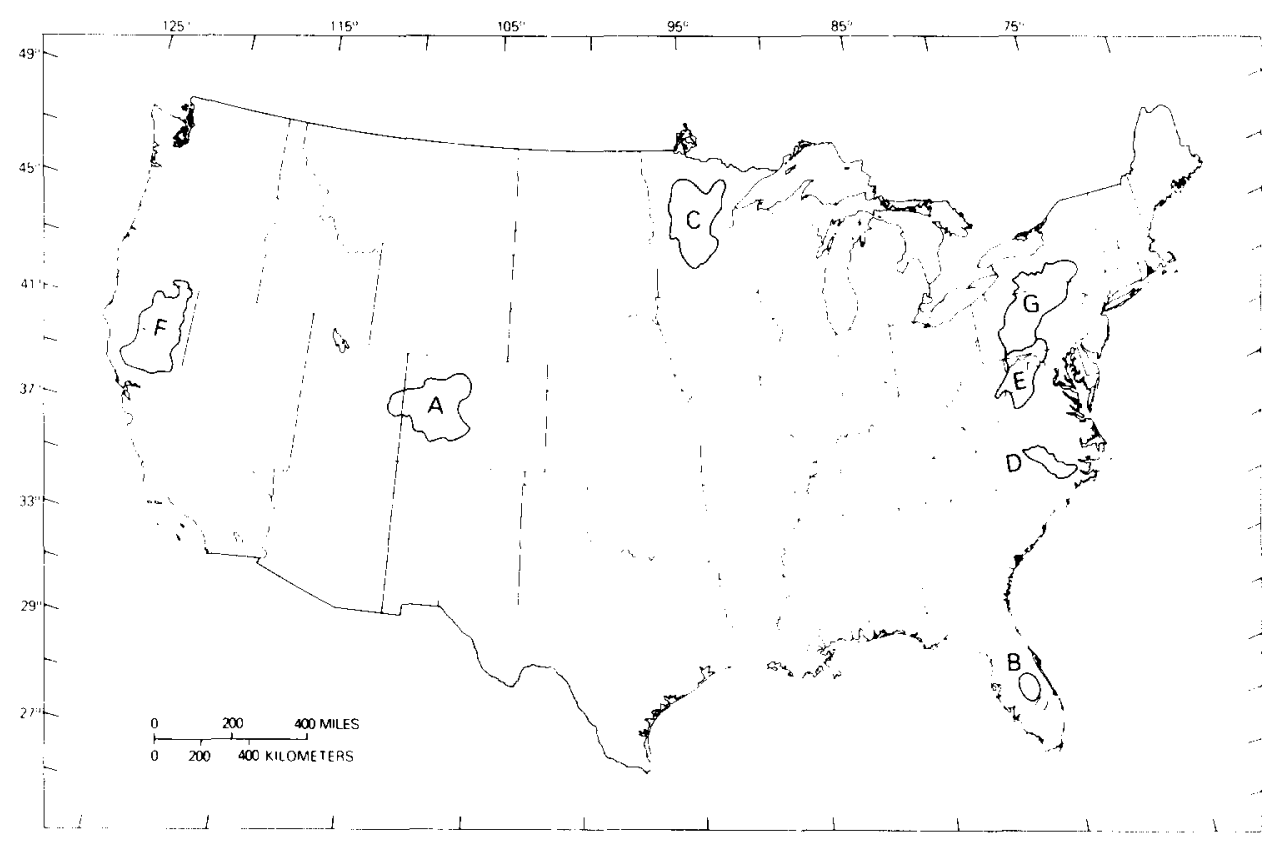

Fig. 1. River basins discussed in this paper. (A) Colorado River above Cisco, Utah; (B) Kissimmee River above Lake Okeechobee, Florida; (C) Mississippi River above Anoka, Minnesota; (D) Neuse River at Streets Ferry Bridge near Vanceboro, North Carolina; (E) Potomac River above Point of Rocks. Maryland; (F) Sacramento River above Sacramento. California: (G) Susquehanna River above Harrisburg, Pennsylvania.

decay. These basins lack large reservoirs that would effectively increase the residence time of waters within the basin and lower the direct-runoff component for the basin.

\section{MODEL OF TRITIUM CONCENTRATIONS IN BASIN OUTFLOW}

The river water flowing out of each basin includes runoff from recent precipitation (the within-year component) and runoff from long-term reservoirs within the basin. The tritium concentration in the outflow from the basin, therefore, is a mixture of these two sources and is described by

$$
C_{\mathrm{o}}=n C_{\mathrm{r}}+m C_{\mathrm{g}}
$$

where $C_{\mathrm{o}}$ is the tritium concentration in the outflow water, $C_{\mathrm{r}}$ is the tritium concentration in the runoff of waters that reside in the basin less than 1 year, $C_{\mathrm{g}}$ is the tritium concentration in runoff from the long-term reservoir, and 
$n$ and $m$ are the fractions that each source contributes to the outflow, such that

$n+m=1$

A significant fraction of the within-year runoff consists of water from the current storm and preceding storms. Kennedy et al. (1986) used isotopic data (oxygen-18, deuterium, and tritium) to identify sources of runoff during storms and found that isotopic signatures of previous storms were present in the runoff. By modeling a river basin system on a yearly basis and using weighted averages for isotopic concentrations in precipitation, storm-tostorm differences are taken into account. In the present model, within-year runoff is taken to mean waters that reside in the basin for less than 1 year and $C_{\mathrm{r}}$ is equivalent to $C_{\mathrm{p}}$, the weighted average of concentration in precipitation for that year.

The values of $C_{\mathrm{p}}$ for the years 1953-1983 were from Michel (1989b). Values for $C_{0}$ were obtained from the data of the US Geological Survey tritium network for the years each station was active. The unknown values in eq. (1) are the two scaling factors, $n$ and $m$, and the average tritium concentration in runoff from the long-term reservoir, $C_{\mathrm{g}}$.

The long-term reservoir is most likely a series of reservoirs with different characteristics and residence times. The tritium concentrations in water from these reservoirs can vary from 0 tritium units (TU) for old ground waters ( $>50$ years) to concentrations that may reach 50-100 TU for reservoirs with residence times on the order of 20 years. The tritium concentrations in many of these reservoirs will be higher than those in present-day precipitation because of the residual effects of the peaks in tritium concentrations in precipitation in the $1950 \mathrm{~s}$ and $1960 \mathrm{~s}$. In the present model, the long-term reservoir system is treated as a well-mixed, one-box reservoir with a residence time that is a combination of the many different residence times in the system. Thus, the tritium concentrations in the runoff $\left(C_{\mathrm{g}}\right)$ will respond as if the reservoir was a well-mixed system with a single residence time (Yurtsever and Payne, 1986). The residence time calculated should not be considered to be the residence time of the water in the basin; rather, it is an indicator of the way the reservoir system responds to an input of a tracer or soluble pollutant. For this system, $C_{\mathrm{g}}$ will equal the average tritium concentration in the reservoir, and the change in $C_{\mathrm{g}}$ is given by

$\mathrm{d} C_{\mathrm{g}} / \mathrm{d} t=-\lambda C_{\mathrm{g}}-k\left(C_{\mathrm{g}}-C_{\mathrm{p}}\right)$

where $\lambda$ is the decay constant for tritium $\left(0.0557\right.$ year $\left.^{-1}\right)$ and $k$ is the inverse 
of the apparent residence time of the long-term reservoir of the basin. In eqn. (3) the system is treated as a well-mixed box (Revelle and Suess, 1957) in which precipitation is the only input and in which flow out of the basin and decay are the only losses. The size of the reservoir is kept constant by use of one value of $k$ for both inflow and outflow. Although the size of the reservoir can change during years of above-average or below-average precipitation, such change is assumed to be small relative to the total amount of water in storage. Values from Thatcher (1962) for $C_{\mathrm{p}}$ in the prebomb era can be used to calculate an initial value of $C_{\mathrm{g}}$ for any value of $k$.

This model was used to obtain a series of tritium concentration curves in outflow for each of the river basins for different values of $k, n$, and $m$. A linear regression of the concentrations actually measured in the river against concentrations obtained from the model was done for different values of $k, n$, and $m$. The regression is of the form

$C_{0}=a C_{\mathrm{m}}+b$

where $a$ and $b$ are constants representing the slope and intercept of the equation, respectively. The intercept was chosen as zero as the modeled concentrations should not be offset from measured concentrations. The use of a zero intercept is a special case of the general equation used in cases where the two series should match exactly (Taylor, 1982). Values of $k, n$ and $m$ were varied to optimize the fit of the modeled and measured tritium concentration (that is, to obtain a slope equal to 1 ).

\section{RESULTS}

Results are given in Table 1 . The values $n, m, k$, and $a$ are as defined above and $r$ is the correlation coefficient. The standard uncertainties for the slopes range from 2 to $5 \%$ for the correlations. Modeled concentrations and measured concentrations are shown in Figs. 2(a)-(g).

\section{Colorado River basin}

The Colorado River basin above Cisco, Utah (Fig. 2(a)), includes the headwaters of the Colorado River in western Colorado and eastern Utah but excludes the Green River basin. Drainage from the Gunnison and Dolores rivers is included in the basin, which encompasses about $75000 \mathrm{~km}^{2}$. These waters originate on the western slope of the Rocky Mountains and several areas where the salt content of sediments is high salt (Warner et al., 1985). 

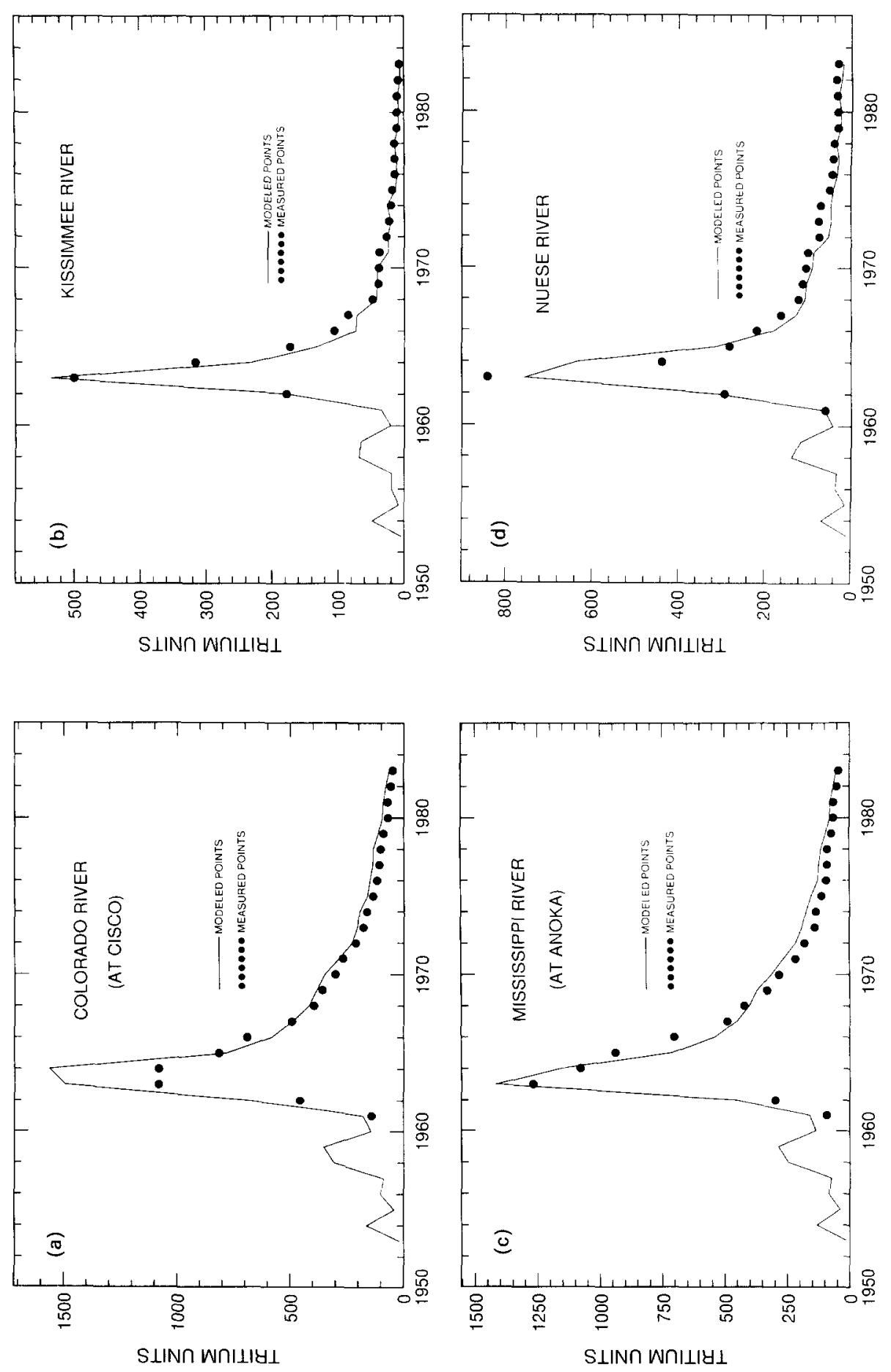


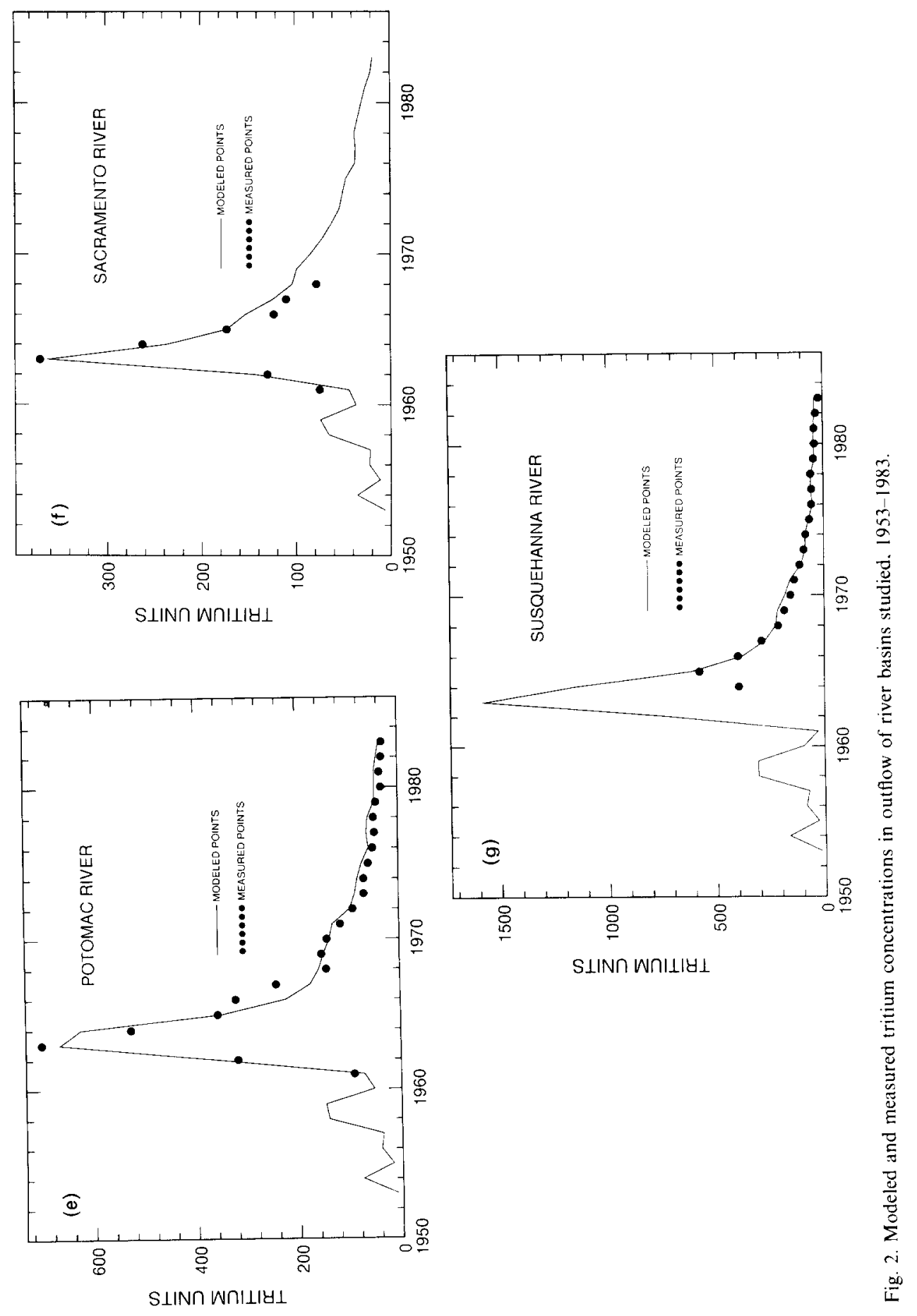




\section{TABLE 1}

Results of a regression of measured against modeled tritium concentrations for the river basins for which long-term tritium data are available

\begin{tabular}{llllll}
\hline River basin & $n$ & $m$ & $k$ & $a$ & $r$ \\
\hline Colorado & 0.40 & 0.60 & 0.07 & 0.996 & 0.971 \\
Kissimmee & 0.94 & 0.06 & 0.4 & 0.95 & 0.983 \\
Mississippi & 0.64 & 0.36 & 0.10 & 1.007 & 0.974 \\
Neuse & 0.73 & 0.27 & 0.09 & 0.998 & 0.967 \\
Potomac & 0.46 & 0.54 & 0.05 & 0.998 & 0.979 \\
Sacramento & 0.35 & 0.65 & 0.10 & 0.988 & 0.972 \\
Susquehanna & 0.80 & 0.20 & 0.10 & 1.004 & 0.989 \\
\hline
\end{tabular}

$n$ is the fraction of the outflow from runoff held in the basin for less than 1 year, $m$ is the fraction from the long-term reservoirs, $k$ (year ${ }^{-1}$ ) is the inverse of the average residence time of the long-term reservoir, $a$ is the slope of a linear regression of measured against modeled concentrations, and $r$ is the correlation coefficient for the regression. The uncertainty in the slope ranges from 2 to $5 \%$.

More than half of the streamflow is derived from long-term reservoirs, which have a residence time of more than 14 years. Water from this river is used for irrigation and the river also collects agricultural return flow (Liebermann et al., 1989), which affects the water quality of the river. The irrigation systems in the basin are similar to those found in the Imperial Valley, California. In studies in the Imperial Valley, Michel and Schroeder (1989) found that agricultural drainage includes waters that have transit times through the unsaturated zone of a decade or more. These anthropogenic influences may have an impact on the residence times of the groundwater reservoir and the relative amounts of ground water and surface runoff in this basin outflow.

\section{Kissimmee River basin}

The Kissimmee River basin above Lake Okeechobee (Fig. 2(b)) is the smallest of the basins studied $\left(4500 \mathrm{~km}^{2}\right)$ and is characterized by the shortest residence time and highest percentage of within-year runoff. Because of the small size and the nature of flow in the basin, model results are the least reliable of the basins studied. The shallow groundwater table and the karst terrain result in a high degree of interaction between ground water and surface water in this basin. Furthermore, the model resolves systems with short residence times poorly, and it cannot adequately distinguish between 2-yearold groundwater runoff and 1-year-old surface runoff. 


\section{Mississippi River}

The Mississippi River at Anoka, Minnesota (Fig. 2(c)) drains a basin of $53000 \mathrm{~km}^{2}$ that is entirely within Minnesota. The major groundwater aquifers are composed of either glacial drift or sedimentary rocks that are extensively tapped for industrial and municipal water supply within the basin (Albin and Bruemmer, 1987). Almost two-thirds of the outflow from this basin consists of waters that have been in the basin for less than 1 year. The average residence time for the long-term reservoirs of the basin is about 10 years. It is likely that the composition and residence time of the ground water in streamflow have been affected by the withdrawal and return of ground waters after use.

\section{Neuse River basin}

The Neuse River above Streets Ferry Bridge near Vanceboro, North Carolina (Fig. 2(d)), drains a basin of approximately $11000 \mathrm{~km}^{2}$ in the Piedmont and part of the Coastal Plain physiographical provinces (Billingsley et al., 1957). Almost three-fourths of the outflow of the river consists of waters that have resided in the basin for less than 1 year. Although use of surface water for municipal and agricultural purposes is extensive, such use does not significantly delay outflow from the basin. Ground water is withdrawn by many small communities along the river, and this ground water eventually discharges to the Neuse River after use. These discharges, though smaller than those of the major cities, could affect the residence times calculated for ground waters in this basin.

\section{Potomac River basin}

The Potomac River at Point of Rocks, Maryland (Fig. 2(e)), drains a basin covering $27000 \mathrm{~km}^{2}$ in parts of Pennsylvania, West Virginia, Virginia, and Maryland. The northern border of this watershed abuts the southern border of the Susquehanna River basin. Some water is used upstream from Point of Rocks for agricultural and municipal purposes, but the main diversions are downstream, in the Washington, DC, area.

The Potomac River is anomalous among the eastern rivers, as over half of its streamflow consists of water from long-term reservoirs. The reservoirs in the basin also have the longest apparent residence time (20 years) of any of the rivers studied. The low percentage of within-year runoff is particularly surprising, because the percentage of within-year runoff in the Susquehanna River, which drains the adjacent basin, is one of the highest of the rivers 
studied. Discharge from carbonate and dolomite aquifers is known to contribute most of the base flow of the Potomac River, especially during the dry summer months (Feltz and Herb, 1978). Model results indicate that the waters in some of these aquifers must have long residence times.

\section{Sacramento River basin}

The Sacramento River at Sacramento, California (Fig. 2(f)), drains an area of approximately $67000 \mathrm{~km}^{2}$ in the Sacramento Valley and surrounding mountains in northern California. The Sacramento River has the lowest percentage of within-year runoff in its outflow of any of the river basins modeled; only one-third of the flow results from runoff of recent wetfall. The river is used for agriculture and discharge of these waters may influence both the ratio of within-year to long-term runoff in the Sacramento River and the apparent residence time of the long-term component of the runoff.

\section{Susquehanna River basin}

The Susquehanna River above Harrisburg, Pennsylvania (Fig. 2(g)), drains $70000 \mathrm{~km}^{2}$ of central Pennsylvania and southern New York. Surface water is commonly withdrawn for agricultural and municipal use; ground water is not used as extensively for water supply as in more arid areas (Taylor, 1984). For the Susquehanna River, the first 2 years of data were omitted from the regression analysis. The two data points during the bomb-induced tritium maximum of 1963-1964 deviate greatly from the model results. In the case of the Susquehanna River, sampling in 1964 was carried out for only 3 months in the winter. Tritium concentrations in precipitation are low in winter because of meteorological factors, so tritium concentrations in winter runoff will be lower than those in average runoff for the year. The averaged value obtained for 1964 would be too low to represent the average tritium concentration in the outflow for that year, and is not used in the regression analysis. Tritium data indicate that within-year runoff is the major component (about $80 \%$ of the total) of outflow in this river.

\section{SUMMARY AND CONCLUSIONS}

A model has been applied to seven river basins for which records of tritium concentrations in the outflow are available beginning in the early 1960s. The model is based on the simplifying assumption that outflow from the basin is from two reservoirs; a within-year reservoir, and a long-term reservoir. Calculations of tritium concentrations in the long-term reservoir are based on the 
assumption that the reservoir is well mixed. Tritium concentrations in precipitation were used as the tritium input, and the responses of the basins to the tritium transient were modeled. The relative contributions of two reservoirs and the residence time of the long-term reservoir were varied until a best fit of modeled and measured data was obtained. Best fits were obtained for all basins, with a correlation coefficient of greater than 0.96 in each case. The results obtained for the Kissimmee River indicate that the model may not be applicable to this basin because residence time of the long-term reservoir is close to the resolution time scale of the model.

The rivers in the western United States (the Colorado and Sacramento Rivers) contain a relatively smaller proportion of within-year runoff in their outflows than the eastern rivers. The lone exception for the eastern rivers is the Potomac River, which derives a large component of its outflow from long-term reservoirs. Most residence times calculated for the ground water in the basins are about 10 years. It should be noted that the residence time calculated is a composite of many different groundwater reservoirs and does not specify any given reservoir; however, the calculated residence time does give an indication of the response of the basin to anthropogenic inputs and the time scale that actions, such as flushing of environmental contaminants from the basin, will require. Efforts to improve the water quality of these rivers will have to take such response times into account.

The modeled tritium concentrations for the river outflow can be applied to hydrological problems within each basin. Because the tritium concentration in the river water generally is greater than that in precipitation, use of tritium concentrations in precipitation does not adequately represent tritium input in studies of systems affected by waters from these rivers. The modeled tritium data furnish additional input information for the study of hydrologic problems in urban and agricultural settings where these river waters are used for water supply.

\section{ACKNOWLEDGMENTS}

The US Geological Survey district offices in the states of California, Florida, Minnesota, North Carolina, Pennsylvania and Utah have been responsible for the sample collection of this program. The program was initiated by F. Pearson, and analyses have been carried out over the past 25 years by $\mathrm{T}$. Wyerman, F. Brookman and many others.

\section{REFERENCES}

Albin, D.R. and Bruemmer, L.B., 1987. Minnesota ground-water quality. US Geol. Surv., Open-File Rep. 87-733, 10 pp. 
Billingsley, G.A., Fish, R.E. and Schipf, R.G., 1957. Water resources of the Neuse River basin, North Carolina. US Geol. Surv., Water-Supply Pap. 1414, 89 pp.

Brown, R.M., 1961. Hydrology of tritium in the Ottawa Valley. Geochim. Cosmochim. Acta, 21: $199-216$.

Feltz, H.R. and Herb, W.J., 1978. Trends in sedimentation. In: K.C. Flynn and W.T. Mason (Eds.), The Freshwater Potomac: Aquatic Communities and Environmental Stress. Interstate Commission on the Potomac River Basin, Rockville, MD, pp. 167-173.

Kennedy, V.C., Kendall, C., Zellweger, G.W., Wyerman, T.A. and Avanzino, R.J., 1986. Determination of the components of stormflow using water chemistry and environmental isotopes, Mattole River basin, California. J. Hydrol., 84: 107-140.

Liebermann, T.D., Mueller, D.K., Kircher, J.E. and Choquette, A.F., 1989. Characteristics and trends of streamflow and dissolved solids in the upper Colorado River basin, Arizona, Colorado, New Mexico, Utah, and Wyoming. US Geol. Surv., Water-Supply Pap. 2358. $64 \mathrm{pp}$.

McPhaden, M.J. and Fine, R.A., 1988. A dynamical interpretation of the tritium maximum in the Central Equatorial Pacific. J. Phys. Oceanogr., 18: 1454-1457.

Michel, R.L., 1989a. Tritium deposition over the continental United States, 1953-1983. In: J.W. Delleur (Ed.), Atmospheric Deposition. IAHS Publ. No. 179, Oxford, UK, pp. 109-115.

Michel, R.L., 1989b. Tritium deposition in the continental United States, 1953-1983. US Geol. Surv., Water-Resour. Invest. Rep., 89-4072, 46 pp.

Michel, R.L. and Schroeder, R.A., 1989. Isotopic composition of drainwaters in the Imperial Valley, California. Trans. Am. Geophys. Union, 70: 1379.

Michel, R.L. and Suess, H.E., 1975. Bomb tritium in the Pacific Ocean. J. Geophys. Res., 80: $4139-4152$.

Revell, R. and Suess, H.E., 1957. Carbon dioxide exchange between atmosphere and ocean and the question of an increase of atmospheric $\mathrm{CO}_{2}$ during the past decades. Tellus, 9: 18-27.

Taylor, J.R., 1982. An Introduction to Error Analysis. University Science Books, Mill Valley, CA, $269 \mathrm{pp}$.

Taylor, L.E., 1984. Groundwater resources of the upper Susquehanna River basin, Pennsylvania. PA Geol. Surv., Water-Resour. Rep. 58, 136 pp.

Thatcher, L.L., 1962. The distribution of tritium fallout in precipitation over North America. IAHS Publ. No. 7, Louvain, Belgium, pp. 48-58.

Warner, J.W., Heimes, F.J. and Middelburg, R.F., 1985. Groundwater contribution to the salinity of the upper Colorado River basin. US Geol. Surv., Water-Resour. Invest. Rep. 84-4198, 113 pp.

Yurtsever, Y. and Payne, B.R., 1986. Mathematical models based on compartmental simulation approach for quantitative interpretation of tracer data in hydrological systems. In: A. Morfis and P. Paraskevopoulou (Eds.), Proc. 5th Int. Symp. of Underground Water Tracing, Institute of Geology and Mineral Exploration, Athens, pp. 341-353. 